\title{
WORKSHOP PENGEMBANGAN MEDIA PEMBELAJARAN BERBASIS MULTIMEDIA BAGI GURU SDN INP 055 KANDEAPI
}

\author{
Rezki Amaliyah $\mathrm{AR}^{1 *}$ \\ Murtafiah $^{2}$ \\ Nurfadilah Mahmud ${ }^{3}$ \\ Nursafitri Amin 4 \\ 1,2,3,4 Universitas Sulawesi Barat, Majene, Indonesia \\ rezkiamaliyah.ar@unsulbar.ac.id ${ }^{1 *}$ \\ murtafiah@unsulbar.ac.id $\left.{ }^{2}\right)$ \\ nurfadilahmahmud@unsulbar.ac.id ${ }^{3}$ ) \\ nursafitriamin@unsulbar.ac.id ${ }^{4)}$
}

Kata Kunci: [Media

Pembelajaran,

Multimedia,

Workshop]

\begin{abstract}
Abstrak: Memasuki era revolusi industry 4.0 memaksa setiap orang untuk mengusai teknologi. Tak terkecuali dalam dunia pendidikan. Guru saat ini dituntut untuk memanfaatkan teknologi dalam pembelajarannya. Namun kenyataannya masih banyak guru yang belum optimal menguasai penggunaan teknologi, apalagi teknologi berbasis multimedia. Sehingga berdampak pada kurang efektifnya proses pembelajaran atau terkesan ketinggalan zaman. Untuk mengatasi masalah tersebut, maka perlu pengembangan keterampilan guru. Tujuannya yaitu memberikan bimbingan dan pendampingan dalam mendesain media pembelajaran dengan memperkenalkan berbagai aplikasi (multimedia). Metode yang digunakan dalam kegitan ini yaitu metode workshop yaitu pelatihan dan bimbingan penggunaan media, dan metode angket untuk mengetahui respon peserta terhadap kegiatan yang telah dilaksanakan. Adapun sasarn peserta workshop yaitu Guru SDN Inp 055 Kandeapi Kabupaten Polewali Mandar, Sulawesi Barat. Adapun hasil yang diperoleh dari kegiatan ini yaitu 98,95\% guru memberikan respon positif terhadap pelaksanaan kegiatan ini baik dari aspek bertambahnya wawasan, keterampilan dan menggunakan hasil pengembangan media dalam proses pembelajaran. Setelah kegiatan ini harapannya adalah qguru lebih kreatif mengembangkan media sehingga proses belajar mengajar dapat berlangsung efektif.
\end{abstract}

Published by:

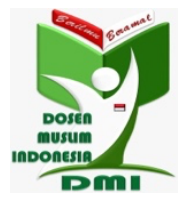

Copyright (C) 2021 The Author(s)

This article is licensed under CC BY 4.0 License (cc) $\mathrm{BY}$

https://dmi-journals.org/jai 


\section{Pendahuluan}

Jenjang sekolah yang paling terdampak terjadinya wabah virus corona (covid-19) adalah Sekolah Dasar. Salah satunya di SDN Inp 055 Kandeapi yang berlokasi di Kecamatan Tinambung Kabupaten Polewali Mandar Provinsi Sulawesi Barat. Selama pandemic virus corona (covid-19), kebijakan pembelajaran dilaksanakan dengan dikombinasikan antara daring dan luring. Sarana dan prasarana yang mendukung proses pembelajaran baik daring maupun luring pada sekolah ini cukup memadai. Guruguru di sekolah tersebut telah memiliki Laptop dan Android. Selain itu, bedasarkan hasil monitoring dan evaluasi pada pembelajaran pada semester sebelumnya, rata-rata siswa dan orang tua siswa sudah memiliki HP Android yang bisa digunakan dalam proses pembelajaran secara daring dan setiap siswa dan guru mendapatkan kuota gratis dari kemendikbud.

Ketika pembelajaran dilakukan secara daring, guru-guru menujukkan ketidaksiapannya. Khususnya dalam penggunaan teknologi informasi. Kebanyakan guru melaksanakan proses pembelajaran hanya dengan menggunakan aplikasi media sosisal seperti whatsapp. Dalam proses pembelajarannya, guru hanya memberikan tugas kepada siswa untuk membaca buku paket yang telah diberikan dan memberikan tugas sebagai latihan. Respon siswa dari proses pembelajaran daring yang dikelola oleh guru seperti ini pun berbeda-beda, namun kebanyakan dari mereka tidak bisa belajar secara mandiri dirumah dengan hanya membaca buku.

Siswa menuntut guru untuk tetap bisa menjelaskan materi pembelajaran sebelum mereka diberikan tugas/latihan agar mereka dapat memahami materi pembelajaran, misalnya dibuat dalam bentuk video penjelasan materi. Dalam hal ini, siswa benar-benar mengalami kesulitan dalam belajar dengan metode pembelajaran yang dilakukan oleh guru. Kesulitan belajar diartikan sebagai ketidakpahaman dan ketidakmampuan anak dalam menyelesaikan tugas-tugas yang diberikan oleh guru. Dalam mengatasi kesulitan belajar siswa tersebut guru-guru kewalahan karena tidak memiliki pengetahuan dan keterampilan yang cukup dalam mengembangkan media pembelajaran yang berbentuk video pembelajaran. Oleh karena itu, untuk mengatasi kesulitan belajar mandiri siswa di rumah secara daring, guru dituntut untuk bisa mengelola dan menyajikan materi pembelajaran dengan baik yang memotivasi siswa untuk belajar, serta memberikan efek belajar menyenangkan, agar kompetensi yang diharapkan dicapai oleh siswa walaupun pembelajaran dilaksanakan dengan metode daring.

Pada Kurikulum 2013 sebenarnya sudah menuntut guru untuk dapat menguasai teknologi. Guru dituntut untuk lebih kreatif dan memiliki inovasi dalam membuat media pembelajaaran sesuai dengan perkembangan zaman. Media pembelajaran merupakan salah satu penyalur pesan antara guru dan siswa. Menurut Hamalik (1989), media pembelajaran adalah alat, metode, dan teknik yang digunakan dalam rangka lebih mengefektifkan komunikasi dan interaksi antara guru dan siswa dalam proses pendidikan dan pengajaran di sekolah. Media pembelajaran dihadirkan dengan harapan agar pembelajaran dapat terarah dan dapat mencapai tujuan pembelajarannya. Menurut Novianto dalam Suyantiningsih dkk (2016), untuk menyukseskan implementasi Kurikulum 2013 salah satunya adalah perangkat pembelajaran dimana media 
pembelajaran merupakan salah satu perangkat pembelajaran yang mempunyai peranan penting dalam proses pembelajaran.

Salah satu pemanfaatan teknologi dalam pembelajaran adalah penggunaan media pembelajaran berbasis multimedia. Multimedia merupakan perpaduan antara berbagai media (format file) yang berupa teks, gambar (vektor atau bitmap), suara, animasi, video, interaksi, dan lainlain yang telah dikemas menjadi file digital (komputerisasi), yang digunakan untuk menyampaikan pesan (Maruti, 2015).

Beberapa hasil penelitian juga menujukan bahwa penggunaan media dalam pembelajaran, terkhusus berbasis multimedia dapat meningkatakan kualitas proses pembelajaran. Seperti hasil penelitian Baharuddin (2015) menunjukan bahwa media pembelajaran berbasis multimedia berpengaruh terhadap efektifitas dan efisiensi pembelajaran. Hasil penelitian Oktafiani dkk (2020) menunjukkan bahwa media pembelajaran berbasis multimedia berimplikasi pada meningkatnya motivasi belajar, memudahkan siswa dalam memahami materi di masa pandemi covid-19, dan memudahkan guru dalam menyampaikan materi pembelajaran.

Berdasarkan situasi tersebut, dilaksanakan kegiatan workshop pengembangan media pembelajran berbasis multimedia bagi guru SDN Inp 055 Kandeapi. Adapun manfaat yang diharapkan dari kegiatan ini adalah guru semakin mahir dan terampil dalam menggunakan teknologi serta mengembangkan media pembelajaran berbasis multimedia, sehingga proses belajar mengajar berlangsung efektif baik secara daring maupun luring.

\section{Metode Pelaksanaan}

Kegiatan pengabdian kepada masyarakat (PKM) ini dilaksanakan pada tanggal 15 Agustus 2021 di SDN Inp. 055 Kandeapi yang dikuti oleh guru dari SDN Inp. 055 Kandeapi sebagai mitra kegiatan. Pelaksanaan kegiatan dilaksanakan di era new normal pandemic covid-19, sehingga perlu batasan jumlah peserta pada setiap kegiatan luring/tatap muka namun tetap memperhatikan protocol kesehatan. Sehingga guru yang mengikuti kegiatan ini hanya 16 orang

Metode yang digunakan dalam pelaksanaan PKM ini adalah metode workshop yaitu pelatihan dan bimbingan pengelolaan media pembelajaran berbasi multimedia serta metode angket untuk mengatahui tingkat pemahaman, ketrampilan dan respon peserta workshop terhadap kegiatan. Adapun indicator kebehasilan dari kegiatan ini adalah:

1. Guru memiliki tambahan wawasan mengenai pengembangan media pembelajaran

2. Guru Memiliki keterampilan untuk mengebangkan media pembelajaran berbasis multimedia

3. Guru akan menerapkan hasil pengembangan media dalam pembelajaran

\section{Hasil dan Pembahasan}

Workshop ini dilaksanakan sesuai dengan jadwal yang telah ditetapkan, serta teknis pelaksanaan kegiatan yang telah disepakati bersama mitra yaitu secara luring atau tatap muka terbatas. Sebelum melaksankan kegiatan pengabdian, tim pelaksana terlebih dahulu mengembangkan tutorial penggunaan media yang akan dilatihkan. 
Kegiatan yang dilaksanakan yaitu memberikan workshop, pelatihan dan bimbingan kepada guru-guru tentang pengembangan media pembelajaran berbasis multimedia dengan 3 aplikasi yaitu ZEPETO, Powtoon dan Kinemaster.

ZEPETO adalah salah satu aplikasi jejaring sosial yang memungkinkan pengguna membuat avatar digital. Pengguna bisa berkreasi membuat avatarnya sendiri, mulai dari tampilan wajah hingga pakaian sehingga membentuk karakter animasi. Dalam pembelajaran sendiri, output animasi dari ZEPETO dapat digunakan dalam membuat media pembelajaran sebagai karakter yang bisa kita gunakan saat mengembangkan video pembelajaran. dalam penelitian Impronah dan Batubara (2021) menyatakan bahwa media video animasi lebih efektif digunakan dalam pembelajaran metamorphosis jenjang sekolah dasar.

Selanjutnya Powtoon adalah aplikasi yang dapat digunakan untuk membuat video dengan fitur animasi unik yang tidak dimiliki platform lainnya. Powtoon sangat membantu dalam membuat media pembelajaran yang berbentuk video. Beberapa peniliti telah mengembangkan media pembelajaran berbasis powtoon. Dalam penelitian Fitriyani (2019) menyatakan bahwa media pembelajaran audio-visual powtoon tentang konsep diri dalam bimbingan kelompok untuk peserta didik di sekolah dasar efektif dapat digunakan untuk metode pembelajaran dikelas. Sejalan dengan itu penelitian Qurrotaini dkk (2020) menyatakan bahwa media video animasi Powtoon efektif digunakan sebagai salah satu media pembelajaran alternatif yang digunakan dalam pembelajaran jarak jauh/daring. Kemudian, Purwanti dan Suryani (2018), model discovery learning berbantu powtoon mempengaruhi motivasi siswa.

Terakhir adalah Kinemaster. Kinemaster adalah salah satu aplikasi editing video yang professional berbasis smartphone. Kinemaster mengusung tampilan yang cukup simple akan tetapi menyimpan fitur yang cukup powerfull, sehingga sangat praktis digunakan oleh guru-guru dalam mebuat media pembelajaran berbentuk video. Banyak peneliti tertarik mengembangkan media pembelajaran dengan berbantuan aplikasi Kinemaster. Diantaranya, Penelitian Winarsih dkk (2021) menujukkan bahwa pengembangan bahan ajar berbasis aplikasi Kinemaster pada pelajaran seni budaya sangat efektif jika diterapkan saat pandemic. Amelia dan Arwin (2020), media pembelajaran berbasis aplikasi Kinemaster pada pembelajaran tematik terpadu di kelas III SD Negeri 36 Koto Panjang dinyatakan sangat layak dan sangat praktis.
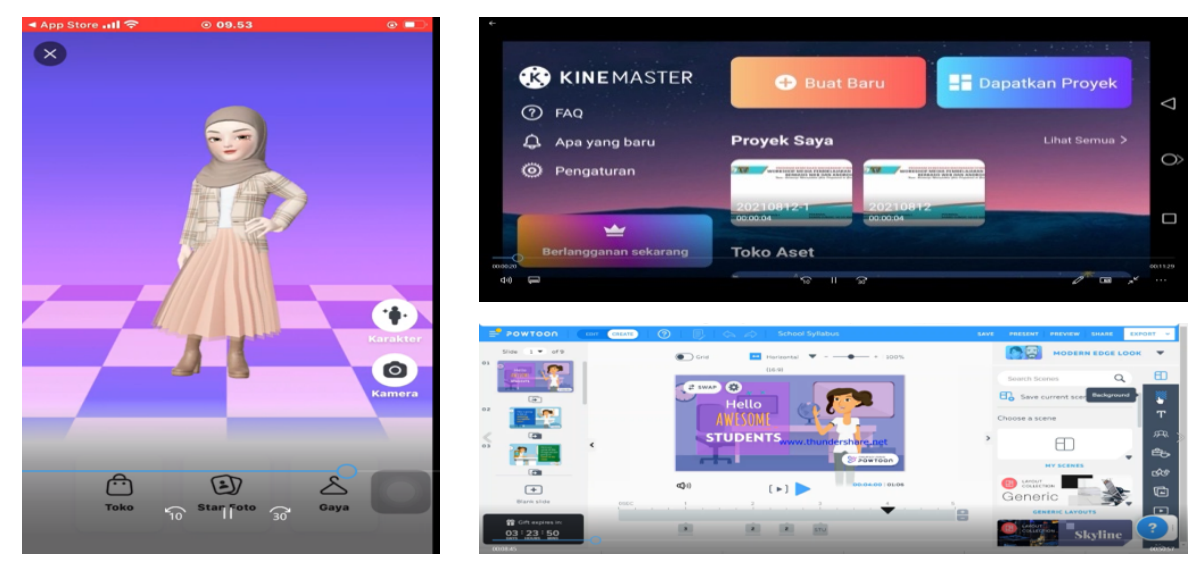

Gambar 1. Tampilan Aplikasi 

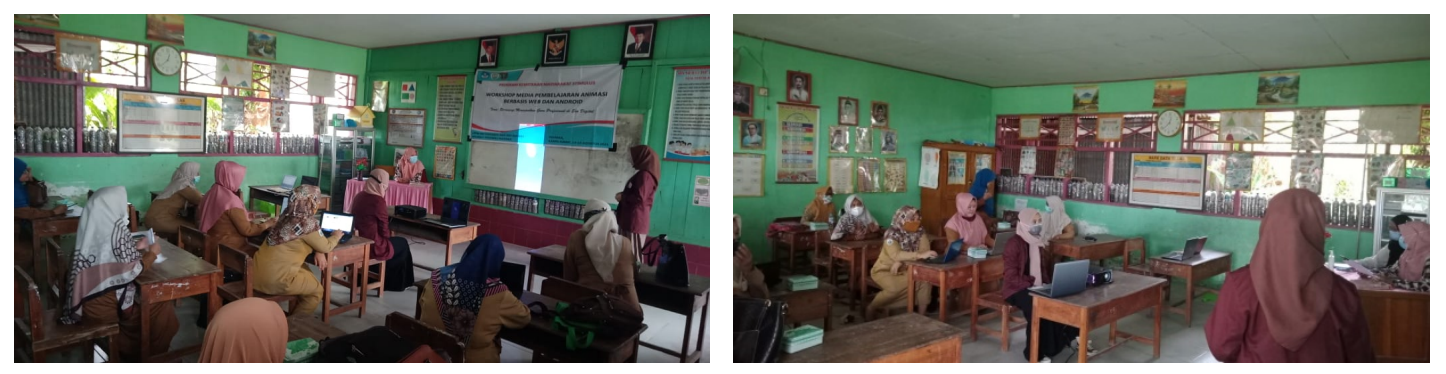

Gambar 2. Dokumentasi Kegiatan berikut:

Adapun hasil analisis angket respon peserta pada kegiatan PKM ini pada table

Tabel 1. Hasil Respon Peserta PKMS

\begin{tabular}{llc}
\hline No. & Aspek yang dinilai & $\begin{array}{c}\text { Hasil } \\
\text { Respon }\end{array}$ \\
\hline 1 & Tambahan Wawasan & $99 \%$ \\
2 & Keterampilan & $97,9 \%$ \\
3 & Penerapan dalam & $100 \%$ \\
& Pembelajaran & \\
\hline \multicolumn{2}{r}{ Rata-Rata } & $\mathbf{9 8 , 9 5 \%}$ \\
\hline
\end{tabular}

Pada Tabel 1, menujukkan bahwa dengan adanya kegiatan ini, wawasan guru tentang pentingnya media pembelajaran bertambah yaitu 99\%, keterampilan guru dalam mengembangkan media pembelajaran berbasi multi media sebesar $97,9 \%$ dan Guru yang menyatakan akan menggunakan media tersebut dalam proses pembelajran sebesar $100 \%$. Hal ini terindikasi bahwa guru sangat merespon positif kegiatan pengabdian ini.

Guru-guru cukup antusias mengikuti kegiatan workshop ini, karena baru pertamakali mereka mendapatkan pelatihan khusus dalam mendesain media pembelajaran sekaligus dengan diperkenalkannya berbagai aplikasi (multimedia). Penggunaan berbagai aplikasi dalam mendesain media pembelajaran dengan memadukan berbagai aplikasi yang memuat berbagai fitur seperti animasi, teks, video, gambar dan audio diharapkan mampu dikuasai oleh semua guru sehingga proses pembelajaran berlangsung efektif. Beberapa kegiatan pelatihan pun sering dilakukan oleh pengabdi yang bertujuan untuk meningkatkan keterampilan guru dalam mengembangkan media pembelajaran. Seperti, Ardiansyah (2020) melaksanakan kegiatan Pelatihan Merancang dan Mengembangkan Multimedia Pembelajaran untuk Guru di SD Negeri Bajangan Kabupaten Pasuruan, setelah mengikuti pelatihan ini guru tak hanya memiliki pengetahuan tentang multimedia pembelajaran, tetapi juga mampu mengembangkan program multimedia pembelajaran untuk proses pembelajaran mereka di kelas. Selanjutnya, Suwarsito dan Mustafidah (2020) Peningkatan Kemampuan Mengembangkan Media Ajar Berbasis ICT bagi Guru-Guru SMP Muhammadiyah 2 Karanglewas dengan hasil kegiatan pada ini dapat membantu guru dalam melakukan inovasi pembelajaran sehingga dapat mengurangi kejenuhan dan membangkitkan motivasi siswa dalam mengikuti pelajaran. Kemudian, Rosalina dan Sofiarini (2021) Pelatihan Pembuatan Vidio Pembelajaran Menggunakan Aplikasi 
Kinemaster bagi Guru Sekolah Dasar Gugus 10 Kecamatan Lubuklinggau Utara II Hasil dari pengabdian kepada masyarakat ini adalah guru sekolah dasar gugus 10 dapat membuat media pembelajaran berupa video menggunakan aplikasi KineMaster.

\section{Kesimpulan}

Kegitan Pengabdian bagi Masyarakat dalam bentuk Workshop Media Pembelajaran Berbasis Multimedia sangat diminati oleh guru-guru. Kegiatan ini mampu meningkatkan pemahaman dan keterampilan guru dalam hal penggunaan teknologi dalam pembelajaaran. Harapan kami setelah kegiatan ini guru-guru mampu mengelola kelas baik secara daring maupun luring dengan menyajikan konteks materi dalam bentuk video dengan memadukan berbagi aplikasi sehingga proses belajar mengajar berlangung efektif dan efisien.

\section{Ucapan Terimakasih}

Kegiatan Pengabdian bagi Masyarakat ini dapat terlaksana karena adanya dukungan dari berbagai pihak, yaitu Dekan FKIP Universitas Sulawesi Barat, TIM Pengabdi yang solid, serta Guru-guru SDN INP 055 Kadeapi Kabupaten Polewali Mandar Sulawesi Barat yang telah bersedia menjadi mitra dan sangat antusias mengikuti kegitan ini. Serta semua pihak yang telah membantu pelaksanaan kegitan ini, rekan sejawat dan mahasiwa Universitas Sulawesi Barat yang terlibat dalam kegiatan ini, terimaksih atas bantuannya.

\section{Referensi}

Amelia, Vira dan Arwin. (2020) Pengembangan Media Pembelajaran Berbasis Aplikasi Kinemaster Pada Pembelajaran Tematik Terpadu di Kelas III Sekolah Dasar. Jurnal Inovasi Pendidikan dan Pembelajaran Sekolah Dasar, 4(2), https://doi.org/10.24036/jippsd.v4i2.112274

Ardiansyah, A., \& Asfiyak, K. (2020). Pelatihan Merancang dan Mengembangkan Multimedia Pembelajaran untuk Guru di SD Negeri Bajangan Kabupaten Pasuruan. Amalee: Indonesian Journal of Community Research and Engagement, 1(2), 125-137. https://doi.org/10.37680/amalee.v1i2.368

Baharuddin. (2015). Pengembangan Media Pembelajaran Berbasis Multimedia Interaktif Sekolah Menengah Kejuruan Terhadap Efektif dan Efisiensi Pembelajaran. Jurnal Inovasi dan Teknologi Pembelajaran, Volume 1(2), 115-126, http://dx.doi.org/10.17977/um031v1i22015p115

Nina Fitriani. (2019). Pengembangan Media Pembelajaran Audio-Visual Powtoon Tentang Konsep Diri dalam Bimbingan Kelompok untuk Peserta Didik Sekolah Dasar.Jurnal Tunas Bangsa,6(1), 104-114. Retrieved from https://ejournal.bbg.ac.id/tunasbangsa/article/view/950

Hamalik, Oemar. 1989. Media Pendidikan. Bandung : Citra Aditya

Impronah, Iim; Batubara, Hamdan Husein. (2021) Pengembangan Media Video Animasi Zepeto untuk Materi Metamorfosis Kupu-Kupu untuk SD/MI. EduBase : Journal of Basic Education, [S.l.] 2(2), 88-100, https://doi.org/10.47453/edubase.v2i2.392 
Maruti , Endang Sri. (2015). Pengembangan Media Pembelajaran Keterampilan Menyimak dan Membaca Berbasis Multimedia Interaktif Siswa Kelas IV Sekolah Dasar. Jurnal Premiere Educandum, 5(1), 49 - 58, http://doi.org/10.25273/pe.v5i01.324

Oktafiani, Dian; Lukman Nulhakim; Trian Pamungkas Alamsyah. (2020). Pengembangan Media Pembelajaran IPA Berbasis Multimedia Interaktif Menggunakan Adobe Flash Pada Kelas IV. Mimbar PGSD Undiksha, 8(3), 527-540, http://dx.doi.org/10.23887/jipgsd.v8i3.29261

Purwanti, Kartika Yuni dan Suryani, Ela. (2018). Pengaruh Discovery Learning dengan Pendekatan Scientific Berbantuan Powtoon terhadap Motivasi dan Kemampuan Berpikir Kritis. JANACITTA Journal of Primary and CHildren's Education, 1(1), http://dx.doi.org/10.35473/jnctt.v1i1.17

Qurrotaini ,Lativa; Tri Widya Sari; Venni Herli Sundi; Laily Nurmalia. (2020). Efektivitas Penggunaan Media Video Berbasis Powtoon dalam Pembelajaran Daring. Prosiding: Seminar Nasional Penelitian LPPM Universitas Muhammadiyah Jakarta, Retrieved from https://jurnal.umj.ac.id/index.php/semnaslit/article/view/7869

Rosalina, Elya dan Sofiarini, Andriana. (2021). Pelatihan Pembuatan Video Pembelajaran Melalui Aplikasi Kinemaster bagi Guru-Guru Sekolah Dasar Gugus 10 Kecamatan Lubuklinggau Utara II. P3MKIL YLIP (Yayasan Linggau Inda Pena) South Sumatera, Indonesia, 2(1), Retrieved from https://jurnal.lp3mkil.or.id/index.php/bnl/article/view/68

Suyantiningsih, Isniatun Munawaroh, dan Sisca Rahmadona . (2016). Pengembangan Multimedia Pembelajaran Berbasis Scientific Approach Terintegrasi Nilai Karakter. Jurnal Kependidikan, 46(1), 1-13, Retrieved from https://media.neliti.com/media/publications/122285-ID-pengembanganmultimedia-pembelajaran-ber.pdf

Suwarsito dan Hindayati Mustafidah. (2020). Peningkatan Kemampuan Mengembangkan Media Ajar Berbasis Ict Bagi Guru-Guru Smp Muhammadiyah 2 Karanglewas (Improving The Ability To Develop Ict-Based Learning Media For Teachers Of Smp Muhammadiyah 2 Karanglewas). Prosiding: Seminar Nasional Hasil Penelitian dan Pengabdian pada Masyarakat V LPPM - Universitas Muhammadiyah Purwokerto ISBN: 978-602-6697-66-0 Retrieved from https://semnaslppm.ump.ac.id/index.php/semnaslppm/article/download/194/189

Winarsih; Susanto, Moh. Rusnoto; Dwi Susanto. (2021). Efektivitas Pengembangan Bahan Ajar Seni Budaya Melalui Aplikasi Kinemaster dimasa Pandemi Covid-19. Jurnal SOSIOHUMANIORA, 7(2), Retrieved from https://jurnal.ustjogja.ac.id/index.php/sosio/article/view/9986/4339 